\title{
WHAT WOULD A SOCIOLOGY APPLIED TO TRANSLATION BE LIKE?
}

\author{
Oscar Diaz Fouces \\ Universidade de Vigo \\ Esther Monzó \\ Universitat Jaume I
}

\begin{abstract}
"Penseu que el mirall de la veritat s'esmicolà a l'origen en fragments petitíssims, i cada un dels trossos recull tanmateix una engruna d'autèntica llum".
\end{abstract}

Salvador Espriu (1948)

\begin{abstract}
"Remember that the mirror of truth was shattered in the beginning into tiny fragments, and yet each bit reflects a spark of genuine light".

Salvador Espriu, traducció de Philip Polack (1989)
\end{abstract}

Most of the usual definitions of Sociology consider it to be a discipline that deals with the systematic study of human societies, following the accepted rules of scientific methodology. It is also common to emphasise that this is not a unitary science, but rather a way of dealing with the collective side of human phenomena. This circumstance becomes especially apparent in the wide range of topics that could be addressed, as well as the number of approaches and applicable methods. Thus, if you look at the list of thematic areas covered by the committees of the International Sociological Association, you can expect to find areas such as the Sociology of Religion, the Sociology of Health or the Sociology of Education, alongside others such as the Sociology of Science, the Sociology of the Arts, and Sociocybernetics, Social Psychology or Social Indicators. In fact, its current list of 55 subject areas is not intended to be closed and conclusive and, therefore, you may want to add on the Sociology of Knowledge, Ethnomethodology, Sociobiology or even the Sociology of Sociology, among many other possibilities. Some scholars suggest that, properly 
speaking, it would be more appropriate to consider Sociology as a bundle of disciplines. At the end of the day, it is very common to refer to a sociological glimpse, which can be diverse, focus on the most varied dimensions of human activity and, indeed, it is easily seen to pervade several other disciplines.

The aim of this monographic issue is to bring together several sociological glimpses of the field of Translation Studies. To stress this fact, we have entitled it "Sociology Applied to Translation" (SAT). This label was chosen because we sought to highlight the opportunity to attract resources, methods and tools from other epistemological areas (those of the social sciences) and perform a selective appropriation of them for our disciplinary field. Indeed, SAT could be constructed by integrating and interpreting selected theories and methodologies. We could build the structure upon the social ontology by Pierre Bourdieu, use the lights provided by the Sociology of Professions to illuminate the reasons, versions and effects of evolution and involution of occupational groups such as ours, establish paths between the plots by following the action-research of Kurt Lewin, adapting and linking theories, methods and applications to get involved in the world and improve it, or to sit down and listen to it and listen to ourselves with a dramaturgical perspective in the style of Erving Goffman or with Garfinkel's Ethnomethodology... It would definitely be an attractive technique for building a theoretical and methodological body that would be applicable to the phenomena of translation and interpretation where the leading characters are the agents and their coexistence.

Note that appropriation as a means of growth is nothing new to us or, for that matter, to many others. In the purest anthropophagic style of De Andrade, Translation Studies has already digested what appeared to be productive from the fields of Linguistics, Literature, Studies on Cognition and Computing. The fundamental difference with respect to the previous examples is that in all these cases, Translation had already in some way been an object of interest and productive study. In the field of Sociology, however, this circumstance has not occurred (at least not with the same intensity), except for some worthy exceptions, such as the work of Heinich (1984) or the monograph by Rodriguez Morató (1997) about the professional circumstances of translators of books; also the articles contained in the monographic volume on Traduction: les échanges littéraires internationaux in issue 144 (2002) of the journal founded by Bourdieu entitled Actes de la Recherche en Sciences Sociales. Other exceptions include diverse works about the directionality of exchanges of cultural products, such as the one by Sapiro, and some work concerning the management of multilingualism, such as that of Colomer (1996), which 
contains a rather interesting application of Game Theory. Paradoxically, there is a sociologically-oriented approach called Sociology of Translation (also known as Actor-Network Theory) that is not directly concerned with what the title suggests at first glance (cf. e.g. Akrich, Callon \& Latour 2006), although its applicability to the study of language management processes is far from negligible, as shown by works such as that of Buzelin (2005).

This absorption of propositions from sociology has enabled Translation Studies to furnish itself with relevant and inspiring works. Some remarkably interesting papers in the field of interpretation, like those by Angelelli (2004), Wadensjö (1998), García (2002) or Kahane (1986), are steeped in Erving Goffman's micro-sociological programme, which is aimed at clarifying the structure of the interaction between two or more individuals when they are both physically present, and Garfinkel's Ethnomethodology, directly related to the work of the conversationalists (Sacks, Schegloff, Jefferson).

The aims of the Sociology of Language, Sociolinguistics and Linguistic Planning obviously converge in some areas with those of Translation Studies. This is especially true with regard to the study of the role to be played by interlinguistic management practices in the normalisation of subordinate languages, standardisation and the role of linguistic mediators as encoders, which is evidenced in works such as those by Corbeil (1992), Cronin (1995), Niska (1998), Aragüés (1988), Millán-Valera (2000), Paquin (2000), Xirinacs (1997), Baxter (2002), Diaz, García \& Carreras (2002), Jaffe (1999), and Erkazanci (2008). The introduction to Branchadell \& West (2005) presents an interesting list of papers and monographic works dealing with some of these aspects, and the same volume contains a large number of studies that exemplify them.

From the so-called Sociology of Communication (in itself a disciplinary intersection under construction) we have received notions such as that of the gatekeeper (Lewin 1947), used in works such as those by Vuorinen (1997), Fujii (1988), Hursti (2001) or Hautanen (2006), and sometimes overlapping with sociolinguistic approaches, such as in Davidson (2000). It must not be forgotten, however, that some theoretical instruments produced in the field of Communication Studies can be traced back to work with a clearly defined Translation Studies profile, such as what is known as Lasswell's paradigm, which is almost certainly not too far removed from some of the elements present in Nord (1988), albeit only implicitly.

The Sociology of Professions, an area that is chiefly English-speaking and with chronologically and conceptually distant proposals, is gaining momentum in Translation Studies, in relation to both translation and interpretation. 
Proof of this is the latest volume of Translation and Interpreting Studies (SelaSheffy \& Shlesinger 2009), but, as noted by Turner (2007: 181) for the case of interpretation, "The aspiration of theorising and practically realising the key features of an interpreting profession [...] has been central to the field in various forms for many years". This sociological glimpse has been part of the pool of knowledge in our discipline since the unpublished master's thesis by Tseng (1992), cited in Mikkelson (2001). And the perspectives adopted in its evolution from the feature approach (introduced into our field in Tseng 1992, or Rudvin 2007) to the more recent systemic glimpse (applied in Monzó 2002, 2003) have been represented in our discipline.

However, the proposal that has undoubtedly attracted most attention from researchers in Translation Studies is the economics of practice by Pierre Bourdieu, whose studies reflected a certain amount of interest in the impact of translation activity on the social fields. In our disciplinary neighbourhood, from the earliest contributions that worked primarily with the key concepts of field (Gouanvic 1997) and habitus (Simeoni 1998), the number of contributions which have applied parts of Bourdieu's ontology has increased sharply in recent years (Gouanvic 1999, Wolf 2002, Inghilleri 2003, Sapiro 2003, Sela-Sheffy 2005, Thoutenhoofd 2005, Gouanvic 2007, Heilbron \& Sapiro 2007, Wolf 2007b). Indeed, the degree to which researchers in translation/ interpreting feel that this framework fulfils their objectives has led to the publication of monographs using Bourdieu's ideas as a shared theoretical background, an example being the work published by Inghilleri in 2005, which contained contributions focused mainly on literary translation and interpretation (Blommaert 2005, Buzelin 2005, Gouanvic 2005, Hanna 2005, Inghilleri 2005b, Thoutenhoofd 2005, Vidal Claramonte 2005). In this volume, you will also find proposals that are based on the application of this model and which adopt different objects of study, together with others that use the foundations of Bourdieu's ontology in a less direct way to explain social states and processes.

As we see it, the possibility of actually constructing a field like SAT (without going into futile nominalistic discussions) means necessarily first acknowledging the fact that the varied nature of the contributions included within this framework very probably has to do with the very diversity of methods and instruments, goals and approaches of the sociological glimpse. From this standpoint, we understand that the range of possible sociological approaches to Translation Studies is not circumstantial, but reflects the very nature of this perspective. If we accept that the functionalist approach by Talcott Parsons is no less sociological than Oswald Wilson's Sociobiology, it does 
not seem very legitimate to claim that the studies on interpretation inspired in micro-sociology are any less representative of a hypothetical Sociology of Translation than the application of Pierre Bourdieu's concepts of field, habitus and symbolic capital to the analysis of the translation of American science fiction or the sociolinguistic argument that communities which use minority languages have to practise forms of compulsory translation in order to gain access to international markets. Of course, it is absolutely legitimate to hypothesise the existence of $a$ Sociology of Translation in the strict sense of the word, to attempt to delimit the scope of a sociological approach that is useful to explain phenomena related to translation (as does, for example, Pym 2006) or to describe and to configure the scientific space of a Sociology of Translation (sometimes with direct references to a hypothetical social turn or even a Sociology of Translation Studies), as is the case of Chesterman (2006), Gambier (2006), Pöchhacker $(2006)$ or Wolf $(2006,2007)$ (Wolf's contribution in this volume challenges this option). In any case, for the time being, this is not the aim of the editors of the volume you now have in your hands.

This volume has no intention whatsoever to cover all the possible views at our disposal as a disciplinary field or to summarise a hypothetical "Sociology of Translation". Based on the idea that theoretical, methodological and sometimes even epistemological perspectives are different, coexistent and equally subject to the dictates of scientific method, the aim of this volume is to highlight the interest in learning more about what sociology can tell us when we invite it round to our place. The danger, however, is obvious: building a branch of our studies on borrowed foundations could lead us to a scattered collection of isolated ideas. The efforts made to gather research works, like the one proposed in this second issue of MonTI, provide models, methods, data and contexts that help us understand the multifaceted phenomena of translation and interpretation, and constitute an invitation to keep on with the collective construction of the space for SAT with new proposals that expand even further the diversity of contexts, data and conclusions, which make it possible to share the same theoretical models for evaluating hypotheses in other contexts, to follow the same methods for different purposes, to accumulate new data from different populations or to raise new questions about the conclusions that are put forward. It becomes essential to grasp the worldview provided by the different sociological theories and test their validity for our field. We need more studies that share the framework and that allow us to see whether the hypotheses remain valid beyond moments in time, territorial spaces or social agents. We are sure this collection will inspire you to continue and replicate research studies, and we hope that this inspiration may become 
a collective task performed by our area in order to further the evolution of SAT.

\section{References}

AKrich, Madeleine; Michel Callon \& Bruno Latour. (2006) Sociologie de la traduction: Textes fondateurs. Paris: Presses de l'Ecole des Mines.

ANGELELli, Claudia V. (2004) Revisiting the Interpreter's Role. A study of conference, court, and medical interpreters in Canada, Mexico, and the United States (Benjamins Translation Library). Amsterdam, Philadelphia: John Benjamins.

ARAGÜÉs, Chusé (ed.) (1988) Primeras chornadas sobre a traduzión: o papel d'a traduzión en o desembolique d'as luengas: o caso de l'aragonés. Zaragoza: Instituto de Estudios Altoaragoneses \& Gara d'Edizions.

BAXTER, Robert N. (2002) "El paper de la traducció en la consolidació de la percepció social del gallec com a Abstandsprache". Quaderns 7. pp. 167-181.

BlommaERT, Jan. (2005) "Bourdieu the Ethnographer: The Ethnographic Grounding of Habitus and Voice". The Translator 11: 2. pp. 219-236.

BOURDIEU, Pierre. (1971) "Genèse et structure du champ religieux". Revue française de sociologie 12. pp. 295-334.

Bourdieu, Pierre. (1972) Esquisse d'une théorie de la pratique, précédée de trois études d'ethnographie kabyle. Geneva: Droz.

Bourdieu, Pierre. (1980) Le sens pratique. Paris: Éditions de Minuit.

BRANCHADELL, Albert \& Lovell Margaret West (eds.) (2005) Less translated languages (Benjamins translation library). Amsterdam: John Benjamins.

Buzelin, Hélène. (2005) "Unexpected Allies: How Latour's Network Theory Could Complement Bourdieusian Analyses in Translation Studies". The Translator 11: 2. pp. 193-218.

Colomer, Josep M. (1996) "To translate or to learn languages? An evaluation of social efficiency". International journal of the sociology of language 121. pp. 181-197.

CORBEIL, Jean-Claude. (1992) "Relation entre traduction, développement et aménagement linguistique". Turjuman 1: 2. pp. 7-16.

Cronin, Michael. (1995) "Altered States: Translation and Minority Languages". TTR VIII: 1. pp. 85-103.

Chesterman, Andrew. (2006) "Questions in the Sociology of Translation". In: Ferreira Duarte, J.; A. Assis Rosa \& T. Seruya (eds.) 2006. Translation Studies at the Interface of Disciplines. Amsterdam/Philadelphia: John Benjamins. pp. 9-28.

DAVIDSON, Brad. (2000) "The Interpreter as Institutional Gatekeeper: The Sociallinguistic Role of Interpreters in Spanish-English Medical Discourse". Journal of Sociolinguistics 4: 3. pp. 379-405. 
DE ANDRADE, Oswald. (1928 [1970]) "Manifesto Antropófago". In: Obras Completas. Do Pau Brasil à Antropofagia e às Utopias: manifestos, teses de concursos e ensaios. Rio de Janeiro: Civilização Brasileira. pp. 18.

Diaz FoUCES, Oscar; Marta García González \& Joan Costa Carreras (eds.) (2002) Traducció i dinàmica sociolingüistica. Barcelona: Llibres de l'índex.

ERKAZANCI, Hilal. (2008) "Language Planning in Turkey: a Source of Censorship on Translations". In: Seruya, T. \& M. L. Moniz (eds.) 2008. Translation and Censorship in Different Times and Landscapes. Newcastle: Cambridge Scholars Publishing. pp. 241-251.

EsPRIU, Salvador. (1989) Primera historia d'Esther. The Story of Esther (The Anglo-Catalan Society Occasional Publications). Sheffield: Sheffield Academic Press. Translated by P. Polack.

FujII, Akio. (1988) "New Translation in Japan". Meta XXXIII: 1. pp. 32-37.

Gambier, Yves. (2006) "Pour une socio-traduction". In: Ferreira Duarte, J.; A. Assis Rosa \& T. Seruya (eds.) 2006. Translation Studies at the Interface of Disciplines. Amsterdam/Philadelphia: John Benjamins. pp. 29-42.

GARCÍA, Marta. (2002) "Socioloxías do saber común: interpretación e a metáfora do teatro ( $\mathrm{Na}$ busca dun modelo aplicable á predicción de elementos verbais e non verabis nos discursos interpretables)". Traducción \& Comunicación 3. pp. 35-65.

GARFINKEL, Harold. (1967) Studies in ethnomethodology. Englewood Cliffs, New Jersey: Prentice-Hall.

Goffman, Erving. (1956) The Presentation of Self in Every Day Life. Edinburgh: University of Edinburgh Press.

GouAnvic, Jean-Marc. (1997) "Translation and the Shape of Things to Come: The Emergence of American Science Fiction in Post-War France". The Translator 3: 2. pp. 123-132.

GouANVIC, Jean-Marc. (1999) Sociologie de la traduction. La science-fiction américaine dans l'espace culturel français des années 1950 (Traductologie). Arras: Artois Presses Université.

GouANVIC, Jean-Marc. (2005) "A Bourdieusian Theory of Translation, or the Coincidence of Practical Instances. Field, 'Habitus', Capital and 'llusio'". The Translator 11: 2. pp. 147-166.

Gouanvic, Jean-Marc. (2007) "Objectivation, réflexivité et traduction: Pour une re-lecture bourdieusienne de la traduction". In: Wolf, M. \& A. Fukari (eds.) 2007. Constructing a Sociology of Translation. Amsterdam: John Benjamins. pp. 79-92.

HANNA, Sameh F. (2005) "Hamlet Lives Happily Ever After in Arabic: The Genesis of the Field of Drama Translation in Egypt". The Translator 11: 2. pp. 167-192. Hautanen, Suvi. (2006) "The Work Process of a Correspondent: A Case Study in Translation Sociology". In: Conway, K. \& S. Bassnett (eds.) 2006. Translation 
in Global News. Proceedings of the conference held at the University of Warwick 23 June 2006. Warwick: University of Warwick - Centre for Translation and Comparative Cultural Studies. pp. 105-112. Full-text version at: <http://www2. warwick.ac.uk/fac/arts/ctccs/research/tgn/events/tgn/translation-in-globalnews-proceedings.pdf>.

HeILBRON, Johan \& Gisèle Sapiro. (2002) Traduction: les échanges littéraires internationaux. Special issue of Actes de la recherche en sciences sociales 144.

HeIlbron, Johan \& Gisèle Sapiro. (2007) "Outline for a sociology of translation: Current issues and future prospects”. In: Wolf, M. \& A. Fukari (eds) 2007. Constructing a Sociology of Translation. Amsterdam: John Benjamins. pp. 93-107.

HeINICH, Nathalie. (1984) "Les traducteurs littéraires : l'art et la profession". Revue française de sociologie 25. pp. 264-280.

HURSTI, Kristian. (2001) "An insider's view on transformation and transfer in international news communication: an English-Finnish perspective". The Electronic Journal of the Department of English at the University of Helsinki 1: 'Translation Studies' (Ritva Leppihalme, ed.). Full-text version at: <http:// blogs.helsinki.fi/hes-eng/volumes/volume-1-special-issue-on-translation-studies/an-insiders-view-on-transformation-and-transfer-in-international-newscommunication-an-english-finnish-perspective-kristian-hursti/>.

INGHILLERI, Moira. (2003) "Habitus, Field and Discourse: Interpreting as a socially situated activity". Target 15: 2. pp. 243-268.

INGHILLERI, Moira. (2005a) Bourdieu and the Sociology of Translation and Interpreting. In: The Translator. Manchester: St. Jerome.

INGHILLERI, Moira. (2005b) "The Sociology of Bourdieu and the Construction of the 'Object' in Translation and Interpreting Studies". The Translator 11: 2. pp. 125-145.

JAFFE, Alexandra. (1999) "Locating Power: Corsican Trasnlators and Their Critics”. In: Blommaert, J. (ed.) 1999. Language Ideological Debates. Berlin/New York: Mouton de Gruyter. pp. 39-66.

KAHANE, Eduardo. (1986) "La interpretación de conferencias o el teatro como metáfora". Cuadernos Hispanoamericanos 431. pp. 175-190.

LEWIN, Kurt. (1946) "Action-research and minority problems". Journal of Social Issues 2: 4. pp. 34-46.

LEWIN, Kurt. (1947) "Frontiers in Group Dynamics: II. Channels of Group Life; Social Planning and Action Research". Human Relations 1: 2. pp. 143-153.

MiKKELSON, Holly. (2001) "Interpreting is interpreting - Or is it?" ACEBO. Fulltext version at: <http://www.acebo.com/papers/interpl.htm>.

Millán-VAlera, Carmen. (2000) "Translation, Normalisation and Identity in Galicia(n)". Target 12. pp. 267-282. 
Monzó, Esther. (2002) La professió del traductor jurídic i jurat. Descripció sociològica de la professió i anàlisi discursiva del transgènere. Barcelona, Castellón: CESCA, Universitat Jaume I. Full-text version at: <http://www.tdx.cesca.es/ TDX-1227102-130850/>.

MONZÓ, Esther. (2003) "Un marc per a la visibilització del traductor: reflexions des de la traducció jurídica i jurada”. Traducción E Comunicación 4. pp. 55-84.

NisKA, Helge. (1998) The Interpreter as a Language Planner. Stockholm: Stockholm University.

NORD, Christiane. (1988) Textanalyse und Übersetzen. Theoretische Grundlagen, Methode und didaktische Anwendung einer übersetzungsrelevanten Textanalyse. Heidelberg: Groos.

PAQUIN, Robert. (2000) "Le doublage au Canada: politiques de la langue et langue des politiques". Meta XLV: 1. pp. 127-133.

PARSONS, Talcott. (1937) The Structure of Social Action: A Study in Social Theory. New York: McGraw Hill.

PÖCHHACKER, Franz. (2006) “'Going social?' On pathways and paradigms in Interpreting Studies”. In: Pym, A.; M. Shlesinger \& Z. Jettmarová (eds.) 2006. Sociocultural Aspects of Translating and Interpreting. Amsterdam/Philadelphia: John Benjamins. pp. 215-232.

PYM, Anthony. (2006) "Introduction: On the social and cultural in translation studies”. In: Pym, A.; M. Shlesinger \& Z. Jettmarová (eds.) 2006. Sociocultural Aspects of Translating and Interpreting. Amsterdam/Philadelphia: John Benjamins. pp. 1-25.

Rodríguez MoRATÓ, Artur. (1997) La problemática profesional de los escritores y traductores. Una visión sociológica. Barcelona: Associació Col-legial d'Escriptors de Catalunya.

Rudvin, Mette. (2007) "Professionalism and ethics in community interpreting". Interpreting 9: 1. pp. 47-69.

SACKS, Harvey; Emanuel A. Schegloff \& Gail Jefferson. (1974) "A simplest systematics for the organization of turn-taking for conversation". Language 50. pp. 696-735.

SAPIRO, Gisèle. (2002) "Limportation de la littérature hébraique en France". Actes de la recherche en sciences sociales 144. pp. 80-98.

SAPIRO, Gisèle. (2003) "The literary field between the state and the market". Poetics 31: 5. pp. 441-464.

SELA-SHEFFY, Rakefet. (2005) "How to be a (recognized) translator: Rethinking habitus, norms, and the field of translation". Target 17: 1. pp. 1-26.

SELA-SHEFFY, Rakefet \& Miriam Shlesinger (eds.) (2009) "Profession, Identity and Status: Translators and Interpreters as an Occupational Group". Special issue Translation and Interpreting Studies, 4: 2. 
Simeoni, Daniel. (1998) "The Pivotal Status of the Translator's Habitus". Target 10: 1. pp. 1-39.

ThoutenHoofd, Ernst. (2005) "The Sign Language Interpreter in Inclusive Education: Power of Authority and Limits of Objectivism". The Translator 11: 2. pp. 237-258.

TSENG, Joseph. (1992) Interpreting as an Emerging Profession in Taiwan. A Sociological Model. Taiwan: Fu Jen Catholic University. Unpublished master thesis.

TURNER, Graham H. (2007) "Professionalisation of interpreting with the community". In: Wadensjö, C.; B. Englund Dimitrova \& A.-L. Nilsson (eds.) 2007. The Critical Link 4: Professionalisation of interpreting in the community. Amsterdam/Philadelphia: John Benjamins. pp. 181-192.

Vidal Claramonte, África. (2005) "Re-presenting the 'Real': Pierre Bourdieu and Legal Translation". The Translator 11: 2. pp. 259-275.

VuORINEN, Erkka. (1997) "News Translation as Gatekeeping". In: Snell-Hornby, M.; Z. Jettmarová \& K. Kaindl (eds.) 1997. Translation as Intercultural Communication. Amsterdam: John Benjamins. pp. 161-172.

WADENSJÖ, Cecilia. (1998) Interpreting as Interaction. London, New York: Longman.

Wilson, Edward O. (1975) Sociobiology: The New Synthesis. MA: Harvard University Press.

Wolf, Michaela. (2002) "Translation Activity between Culture, Society and the Individual: Towards a Sociology of Translation". CTIS Occasional Papers 2. pp. 33-43.

Wolf, Michaela. (2006) "Translating and Interpreting as a Social Practice - Introspection into a New Field”. In: Wolf, M. (ed.) 2006. Übersetzen - Translating - Traduire: Towards a "Social Turn". Münster, Hamburg, Berlin, Vienne \& London: LIT Verlag. pp. 9-19.

WOLF, Michaela. (2007a) "Introduction: The emergence of a sociology of translation”. In: Wolf, M. \& A. Fukari (eds.) 2007. Constructing a Sociology of Translation. Amsterdam: John Benjamins. pp. 1-36.

WOLF, Michaela. (2007b) "The location of the 'translation field'. Negotiating borderlines between Pierre Bourdieu and Homi Bhabha". In: Wolf, M. \& A. Fukari (eds.) 2007. Constructing a Sociology of Translation. Amsterdam: John Benjamins. pp. 109-119.

XIRINACHS I CODINA, Marta. (1997) "La traducción como instrumento de normalización lingüística”. Senez 19. pp. 25-40. 